\title{
Escherichia hermannii
}

National Cancer Institute

\section{Source}

National Cancer Institute. Escherichia hermannii. NCI Thesaurus. Code C86381.

A species of facultatively anaerobic, Gram negative, rod shaped bacterium assigned to the phylum Proteobacteria. This species is motile, produces yellow pigment, ferments glucose, arabinose, mannitol, and rhamnose and is positive for ornithine decarboxylase and indole production. Negative reactions for lactose, melibiose, and sorbitol fermentation, arginine dihydrolase, $\mathrm{H} 2 \mathrm{~S}$ and urease production, lysine decarboxylase, and citrate. Most commonly isolated from environmental sources like drinking water distribution systems. 